Nevertheless, we do not want to detract from the importance of this paper with regard to the use of oxytocin and epidural anaesthesia, both of which are used when indicated in our department. We would also like to emphasise the importance of continuous fetal monitoring in all trials of labour; it should not be forgotten, despite such encouraging reports, that all women delivering after caesarean section are high risk patients and must be monitored accordingly. The delivery should always take place in a unit equipped to deal with the rare emergency.

Ludwig Maximilians Universität,

AVRIL SCHNEIDER

Gunich,

1 Westgren M, Dolfin T, Halperin M, et al. Mode of delivery in the low birth weight foetus. Acta Obstet Gynecol Scand 1985;64: 51-7.

2 Confino E, Ismajovich B, Sherzer A, Peyser RM, David M. Vaginal versus caesarean section oriented approaches in the management of breech delivery. Int $\mathcal{J}$ Gynaecol Obstet 1985 23:1-6.

3 Lavin JP, Stephens RJ, Miodovnik M, Barden TP. Vaginal delivery in patients with a prior cesarean section. Obstet Gynecol 1982;59:135-48.

4 Jarrell MA, Ashmead GC, Mann LI. Vaginal delivery after cesarean section: a 5 year study. Obstet Gynecol 1985;65: 628-32.

\section{Hypotensive and sedative effects of insulin in autonomic failure}

SIR,-The hypotensive effect of systemically administered insulin in patients with autonomic failure described by Dr Christopher J Mathias and colleagues ( 18 July, p 161) might be explained by the fact that insulin is a vasodilator. Using photoelectric plethysmography ${ }^{1}$ to measure blood flow close to superficial subcutaneous injection sites, we have shown that insulin has a local vasodilator action. ${ }^{2}$ Subsequent work has shown that systemic administration of insulin (in doses insufficient to cause hypoglycaemia) also causes vasodilatation. ${ }^{34}$ In view of the findings of $\mathrm{Dr}$ Mathias and coworkers it is interesting that Takata et al found that systemic insulin caused dilatation of both resistance and capacitance vessels in diabetic patients with autonomic neuropathy but not when autonomic function was normal. ${ }^{4}$ They suggested that vasodilatation was a major contributory factor in insulin induced hypotension.

The mechanism of action of insulin induced vasodilatation is obscure, although it may be mediated by $\beta$ adrenergic receptors. ${ }^{3}$ As D Mathias and colleagues suggest, greater sensitivity of deeper visceral vascular beds to the vasodilator effect of insulin may explain why hypotension appeared in their patients before any increases were observed in forearm muscle or finger blood flow.

GaRETH WILliams

Department of Medicine,

Royal Postgraduate Medical School,

London W12 0HS

Division of Chemical Pathology,

United Medical and Dental Schools of Guy's

United Medical and Dental Sch
and St Thomas's Hospitals,

and St Thomas's

1 Challoner AVJ. Photoelectric plethysmography for estimating cutaneous blood flow. In: Rolfe P, ed. Non-invasive physiological measurement. Vol 1. New York: Academic Press, 1979:125-51.

2 Williams G, Pickup JC, Clark A, Bowcock S, Cooke E, Keen H. Changes in blood flow close to subcutaneous insulin injection sites in stable and brittle diabetes. Diabetes 1983;32:466-73.

3 Creager MA, Liang C-S, Coffman JD. Beta adrenergicmediated vasodilator response to insulin in the human forearm. I Pharmacol Exp Ther 1985;235:709-14.

4 Takata S, Yamamoto M, Yagi S, Nata Y, Ikeda T, Hattori N. Peripheral circulatory effects of insulin in diabetes. Angiolog 1985;36:110-6.

\section{Hospital developments in Scotland}

SIR,-I read with great surprise Scrutator's comment that the Minister of Health for Scotland has imposed a building scheme on the Greater Glasgow Health Board that is not considered to be necessary (1 August, p 340). This is simply not true as the developments are the culmination of over 12 years' detailed consultation with all staff, including the members of the medical profession.

Since planning started in 1974 there has been a minimum of three hospital doctors on the planning team, but more often four, in addition to the chief administrative medical officer. Total agreemen was reached with all disciplines, including medical staff, and minutes showing this are available for inspection. One of the doctors was a very well respected consultant surgeon, Mr Ronald Cumming, with over 20 years' experience at the hospital. Mr Parkin was appointed consultant surgeon less than 18 months ago.

When the board made its decision in February 1986 to proceed with the scheme the written advice from the area medical committee was: "All items in phase 1 of the hospital development are necessar and essential for efficient patient management." In short the committee, which consists of every doctor in Shetland, considered the developments, including the new maternity unit, to be essential. The area nursing and midwifery committee, the area dental committee, and the Royal College of Nursing also advised the board strongly that the scheme should proceed. The Confederation of Health Service Employees did not express any opposition, saying only: "Whatever decision was reached it was hoped that it would benefit the patients." The local health council, which is chaired by a retired Shetland doctor who has a deep appreciation of the needs of the local community also gave public support in favour of the scheme at a meeting attended by the chief administrative medical officer.

Thus there was overwhelming support for the scheme to proceed, and the board voted accordingly. Finally, the board received a written report from its senior management team expressing unanimous support for the scheme to start. This team consists of the general manager, the chief administrative medical officer, the chief administrative nursing officer, the chief administrative dental officer, and the treasurer. It is true, how ever, that the chief administrative medical office made certain reservations not expressed previously because of the two consultants having only recently been appointed.

The board quite clearly made the correct decision in view of the weight of advice received, and there is no question of the developments having been imposed on it by the minister.

Shetland Health Board

D C MARCH Shetland 2EI 0QP

\section{The cost of nursing}

SIR, - The English National Board circular 86/65/ ERDB to which Dr K W M Scott refers in his letter (8 August, p 393) states that nursing training institutions "should show that progress is being made towards achieving ... 1532 hours of theoretical instruction [in a three year training programme] which will include study blocks, seminars and clinically based theoretic training sessions."

The English National Board was established by statute "to provide or arrange for others to provide at institutions approved by the Board courses of training with a view to enabling persons to qualify for registration as nurses, midwives and health visitors" (Nurses, Midwives, and Health Visitors Act, -1979). Approval of training institutions is therefore vested in the English National Board and not, as indicated in the letter, with the Royal College of Nursing. The board, in approving institutions, observes the nurse training rules prepared by the United Kingdom Central Council and agreed by parliament; its own agreed criteria; and the requirements in the appropriate European Community directive.

I am sure that Dr Scott is not suggesting that standards of nursing education and training should be less than those expected by the appropriate approving bodies in his own profession, and I am equally certain that readers will recognise that the theoretical element of undergraduate medical training programmes accounts for more than one year.

We in nursing do not have the advantage of supernumerary status for our students, who are considered to be part of the manpower equation. This is obviously totally inappropriate and leads to difficulties such as those indicated by Dr Scott. The statutory bodies, the United Kingdom Central Council, and the national boards consulted with the profession for a solution to this and other issues associated with nursing, midwifery, and health visiting education, and the result was Project 2000. The government has just completed its consultation with the service on Project 2000, and the profession awaits its response.

A commitment to supernumerary status is essential, and the support of our colleagues in the medical and other health care professions would be an indication of their understanding of the position of student nurses. Finally, may I emphasise that supernumerary status does not mean that students will learn nursing in the classroom. It means, rather, that their contract will be educationally directed, and, as a consequence, their acquisition of nursing skills will be structured and meaningful.

DAVID JONES

English National Board for

Nursing, Midwifery, and Health Visiting, London WIP OHA

Sir,-I continue to be dismayed at the attitudes of medical staff towards their professional colleagues (8 August, p 393). As the science and knowledge surrounding medicine increase I am amazed that anyone can say that we should not be improving the quality and quantity of instruction given to trainees. Do we hear doctors say that the type of training given to medical students is now so perfect that no changes should be made to their curriculum? Nurses have been handmaidens to the medical profession for too long, following orders without thought or knowledge. Those days have gone. Nurses must strive to be seen as the professionals they are. We wish to be knowledgeable in our work, caring for patients to the highest standards demanded by ourselves, our professional body, and most of all our patients. This can be achieved only if we attract intelligent men and women to the profession and train them to be knowledgeable and well informed nurses. How can nurses give adequate, much less good, care if their training has not prepared them sufficiently for the work they are to do? It is a disservice to the nursing profession to believe that they do not need to know. The attitude expressed by $\mathrm{Dr} \mathrm{K}$ W M Scott, however, does more discredit to the medical profession than to the nursing profession. If Wolverhampton Health Authority does not think that its nurses should be trained even to the recommended standard it deserves to lose the facility to train nurses because it is not worthy of the responsibility.

LORRAINE K M BROOKS

Llandaff,

Cardiff CF5 2TD 